\title{
Breast Cancer pTis (LCIS) TNM Finding v6 and $v 7$
}

National Cancer Institute

\section{Source}

National Cancer Institute. Breast Cancer pT is (LCIS) TNM Finding v6 and v7. NCI

Thesaurus. Code C48976.

Breast cancer with a finding of lobular carcinoma in situ. (from AJCC 6th and 7th Ed.) 